\title{
Experimental Study on Mechanical Property of Soil-Cement
}

\author{
Hongxia Yang \\ Department of Civil Engineering, Shandong Jiaotong University, Jinan, Shandong, 250023, China \\ yanghongxia0531@163.com
}

Keywords: Soil-cement, Strength, Cement content, Age, Moisture content, Deformation.

\begin{abstract}
Based on test data analysis of soft foundation reinforcement of Ji-He expressway in Shandong province, this paper discussed mechanical properties of soil-cement and variation law. The results showed that the main factors which effect the compressive strength of soil-cement include cement content, age and moisture content. The compressive strength of soil-cement increased with the increasing of cement content, both are a power function relation, along with the age growth and increase, with increase of the moisture content of the soil sample lowers quickly. The relationship of stress-strain is non-linear, showing the elastic-plastic material properties. Besides, compression coefficient of the soil-cement decreased with the increasing of cement content. Deformation modulus, tensile strength and shear strength increased along with the increasing of compressive strength.
\end{abstract}

\section{Introduction}

Ji-He expressway located in the Yellow River downstream alluvial plain, along is quaternary cover area. The open strata mainly is the quaternary powder soil, clay, sand and so on, it's thickness is $150 \mathrm{~m}-400 \mathrm{~m}$.Based on the field geological drilling and indoor test material comprehensive analysis, part of the road belongs to soft foundation which needs reinforcing. Through comparison of several schemes, it decided to adopt soil-cement mixing method. Soil-cement mixing method in soft soil foundation reinforcement is a new technology and is the cement as the solidification agent, through a special deep mixing machine, in the depth of the foundation in the soft soil and cement forced mixing. Cement and soft soil generated a series of physical and chemical reaction, so that the soft soil hard to form has integrity, water stability and quality foundation of a certain strength[1]. At present the technology development experiences only thirty years, no matter from the reinforcement mechanism to the design calculation method and construction technology are the imperfect place to be, some still in the semi-theoretical and semi-empirical state, coupled with the concealment of construction, so the soil-cement were studied by indoor experiments are the important way to ensure the foundation reinforcement effect. This paper according to Ji-He expressway engineering soil-cement mixing method soft foundation reinforcement example, through the indoor experiment, discussing the mechanical properties of soil-cement and its change rules, and providing a theoretical basis for highway soft foundation reinforcement.

\section{Raw Material Physical and Mechanical Properties Test}

Undisturbed soil. Undisturbed soil is taken from K133+000-K136+000 sections of Ji-He expressway following 2.2m.According to the "Test Methods of Soils Highway Engineering” [2], the main physical and mechanical parameters of soil layers are shown in Table 1.Table 1 show that 1, 2, 3, 4 of soil moisture content and porosity ratio is relatively large, the bearing capacity is not more than $100 \mathrm{kPa}$, the soil is poor. When the load is larger, the reinforcement treatment must be taken.

Cement. 32.5 ordinary Portland cement by Shandong cement factory production, its quality qualified.

\section{Test Results of the Soil-Cement Mechanical Properties}

Unconfined Compressive Strength. In the soil and cement, strength grade is given, the main factor which influence unconfined compressive strength is cement content, age and soil moisture 
content.

The Effect of Cement Content on the Compressive Strength. When the cement content is $5-20 \%$, unconfined compression strength of soil-cement is generally $300-3500 \mathrm{kPa}$. the relationship between 28 days unconfined compressive strength and cement content is shown in Fig. 1. According to a large number of indoor data statistics of Ji-He highway, the relationship between 28 days unconfined compressive strength and cement content by formula (1) shows.

$$
\frac{f_{c u 1}}{f_{c u 2}}=\left(\frac{a_{c 1}}{a_{c 2}}\right)^{1.45}
$$

Where, $f_{c u 1}$ is unconfined compressive strength of cement content $a_{c 1}, f_{c u 2}$ is unconfined compressive strength of cement content $a_{c 2}$.

Table 1 The main physical and mechanical parameters of soil layers

\begin{tabular}{|c|c|c|c|c|c|c|c|}
\hline NO. & $\begin{array}{c}\text { Soil } \\
\text { name }\end{array}$ & $\begin{array}{c}\text { Moisture } \\
\text { content } \\
(\%)\end{array}$ & $\begin{array}{c}\text { Unit } \\
\text { gravity } \\
\left(\mathrm{kN} / \mathrm{m}^{3}\right)\end{array}$ & $\begin{array}{c}\text { Porosity } \\
\text { ratio }\end{array}$ & $\begin{array}{c}\text { Plasticity } \\
\text { index }\end{array}$ & $\begin{array}{c}\text { Compression } \\
\text { coefficient } \\
\left(\mathrm{kPa}^{-1}\right)\end{array}$ & $\begin{array}{c}\text { Bearing } \\
\text { capacity } \\
\text { of } \\
\text { foundation } \\
(\mathrm{kPa})\end{array}$ \\
\hline 1 & Silt & 23.8 & 19.01 & 0.717 & 9.3 & 0.146 & 100 \\
\hline 2 & Clay & 42.5 & 17.44 & 1.198 & 23.5 & 0.470 & 85 \\
\hline 3 & Silt & 21.5 & 19.40 & 0.651 & 7.4 & 0.139 & 90 \\
\hline 4 & Clay & 26.3 & 19.01 & 0.784 & 18.9 & 0.607 & 100 \\
\hline 5 & Silty clay & 20.3 & 20.19 & 0.584 & 10.9 & 0.236 & 150 \\
\hline 6 & Clay & 23.9 & 19.89 & 0.666 & 18.4 & 0.249 & 200 \\
\hline
\end{tabular}

Fig. 1 shows that unconfined compression strength increases with increases of cement content. When the cement content is less than $5 \%$, as a result of cement and soil reaction too weak, soil-cement curing degree low, lower strength, discrete is also big. Therefore in the construction of cement mixing method, cement content should be greater than 5\%. According to the existing research data [3,4], cement mixed quantity can be selected between $7 \%-20 \%$ according to the requirements.

The Effect of Age on the Compressive Strength. The relationship between unconfined compressive strength and age is shown in Fig. 2. Fig. 2 shows that compressive strength increases with the growth of the age, generally at the age of more than 28 days have increased significantly. When cement content is 7\%, strength of 90 days is 1.79 times of 28 days, when cement content is $12 \%$, strength of 90 days is 1.83 times of 28 days. Cement mixing ratio is bigger, the compressive strength improved rate is bigger. When the age more than 3 months later, soil-cement strength growth to slow down. Therefore selects 3 months age strength as the standard is suitable for engineering.

The Effect of Soil Moisture Content on the Compressive Strength. Cement content is 10\%, the relationship between unconfined compressive strength of 28 day and moisture content of soil samples is shown in Fig. 3. From the Fig. 3 shows that the compressive strength decreases rapidly with increases of soil moisture content. But the data also showed that $[4,5]$, when the soil natural moisture content is less than $25 \%$, in the soil free water decrease, cement hydration not completely, and soil-cement strength reduce, which seriously affect the soil-cement mixing pile bearing capacity.

The Stress-Strain Curve. By soil-cement specimens 28 days age unconfined compression test to obtain the stress-strain curve is shown in Fig. 4. Fig. 4 shows that the stress-strain relationship is nonlinear relation. In the loading stage begins, stress-strain is approximately linear relationship, behaving as elastic material properties. When the stress reaches a certain value, the stress-strain curve begins to bend, showing plastic material properties. Soil-cement failure under pressure, The axial strain is commonly $0.8 \%-1.2 \%$.

Deformation Modulus. The test results of deformation modulus of soil-cement specimens are shown in Table 2.When the compressive strength is $300-1500 \mathrm{kPa}$, deformation modulus is 38-180MPa, about compressive strength of more than 100 times. 


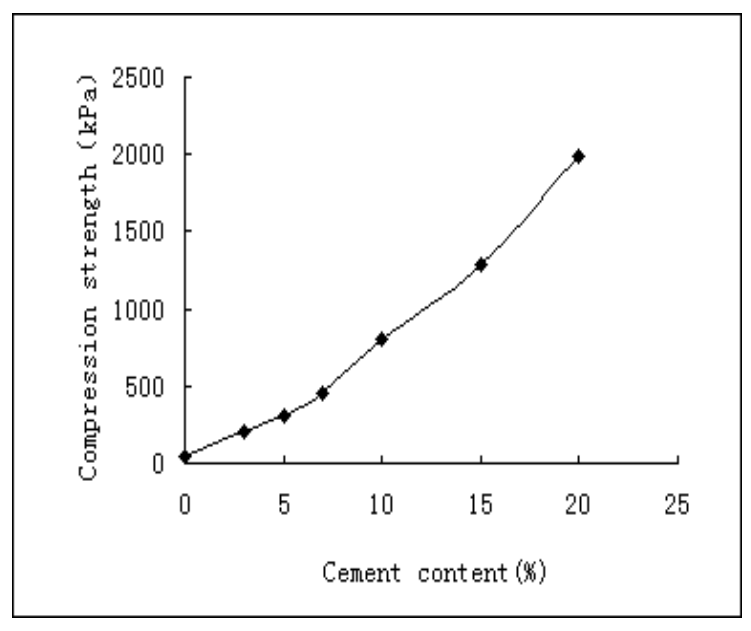

Fig. 1 The relationship unconfined compressive strength and cement content

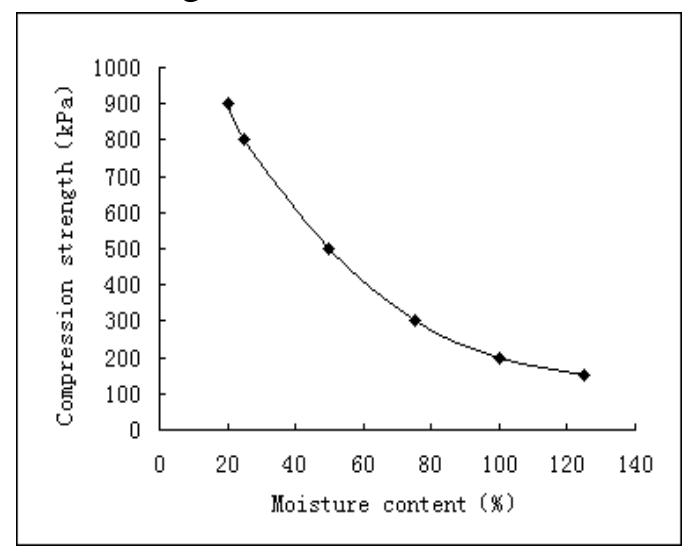

Fig. 3 The relationship unconfined compressive strength and moisture content

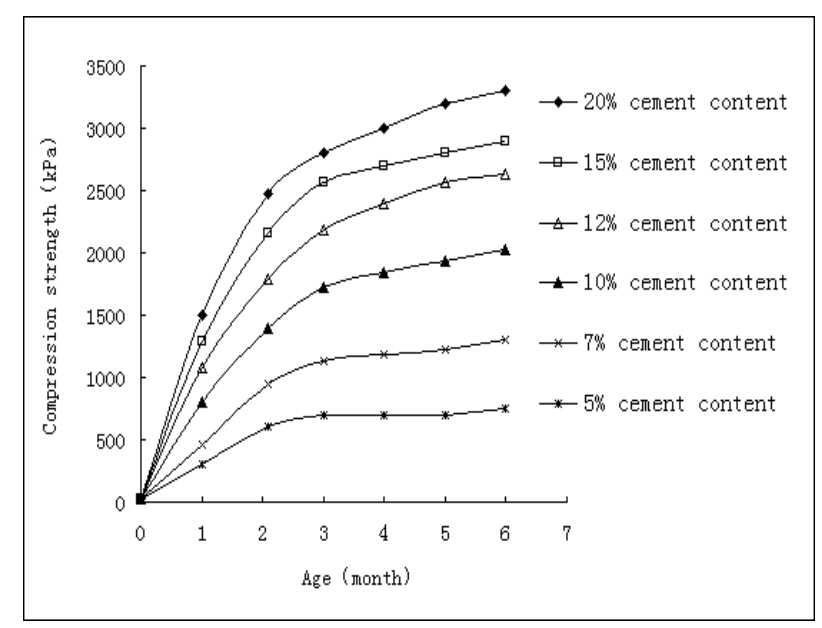

Fig. 2 The relationship unconfined compressive strength and age

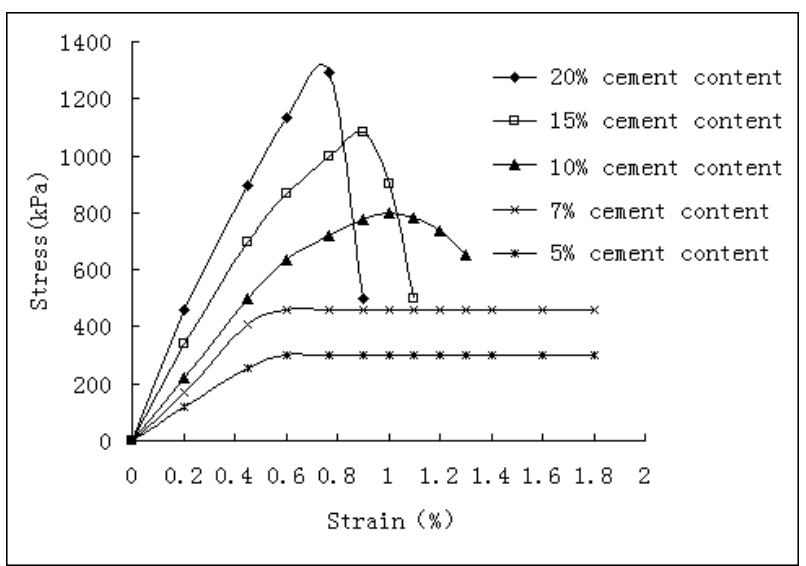

Fig. 4 The stress-strain curve

The Compression Coefficient and Compression Modulus. The compression coefficient of soil-cement decreases with increases of cement content, changes in $(1.8-2.5) \times 10^{-5}(\mathrm{kPa})^{-1}$ range, its corresponding compression modulus is $30-80 \mathrm{MPa}$.

Splitting Tensile Strength. The test results of the soil-cement splitting tensile strength of 28 days age are shown in Table 3. Tensile strength increases with increases of the compressive strength, its is about compressive strength of 1/10-1/15.

Shear Strength. Soil-cement shear strength using direct fast shear test. The test results of shear strength of 28 days age are shown in Table 4.The shear strength increase with increase of unconfined compressive strength. Compared with the original natural soil, cohesive force and internal friction angle are increased multiples, as cement admixture quantity 7\%-15\%, cohesion increased by 5-10 times, internal friction angle increase by 2-3 times.

\section{Conclusions}

The soil cement mixing method is a new technology of the soft foundation reinforcement, no matter from the mechanism of reinforcement to the design calculation method and construction technology are to be further improved.Indoor and outdoor tests study can be for mixing method to provide the theory basis. When soil properties and the strength grade of cement under certain circumstances, the cement content ,age and moisture content are the main factors of the influence on compressive strength.The deformation modulus, tensile strength and shear strength increase with the increase of compressive strength. 
Table 2 Deformation modulus of soil-cement

\begin{tabular}{|c|c|c|c|}
\hline $\begin{array}{c}\text { Cement content } \\
(\%)\end{array}$ & $\begin{array}{c}\text { 28 days unconfined } \\
\text { compressive strength }(\mathrm{kPa})\end{array}$ & $\begin{array}{c}\text { Failure strain } \\
(\%)\end{array}$ & $\begin{array}{c}\text { Deformation } \\
\text { modulus } \\
(\mathrm{kPa})\end{array}$ \\
\hline 5 & 300 & 0.80 & 35200 \\
\hline 7 & 462 & 1.11 & 62300 \\
\hline 10 & 802 & 1.05 & 92100 \\
\hline 12 & 1080 & 0.95 & 133100 \\
\hline 15 & 1287 & 0.93 & 161000 \\
\hline 20 & 1505 & 0.90 & 180100 \\
\hline
\end{tabular}

Table 3 The test results of splitting tensile strength

\begin{tabular}{|c|c|c|c|c|c|}
\hline $\begin{array}{c}\text { Cement } \\
\text { content } \\
(\%)\end{array}$ & $\begin{array}{c}\text { Unconfined } \\
\text { compressive } \\
\text { strength } \\
(\mathrm{kPa})\end{array}$ & $\begin{array}{c}\text { Tensile } \\
\text { strength } \\
(\mathrm{kPa})\end{array}$ & $\begin{array}{c}\text { Cement } \\
\text { content } \\
(\%)\end{array}$ & $\begin{array}{c}\text { Unconfined } \\
\text { compressive strength } \\
(\mathrm{kPa})\end{array}$ & $\begin{array}{c}\text { Tensile } \\
\text { strength } \\
(\mathrm{kPa})\end{array}$ \\
\hline 5 & 308 & 32 & 12 & 1083 & 106 \\
\hline 7 & 450 & 41 & 15 & 1290 & 110 \\
\hline 10 & 805 & 56 & 20 & 1510 & 125 \\
\hline
\end{tabular}

Table 4 The test results of direct fast shear

\begin{tabular}{|c|c|c|c|c|c|c|}
\hline \multirow{2}{*}{$\begin{array}{l}\text { Unconfined } \\
\text { compressive } \\
\text { strength of } \\
\text { natural soil } \\
\text { samples } \\
(\mathrm{kPa})\end{array}$} & \multicolumn{2}{|c|}{$\begin{array}{c}\text { Shear strength parameters } \\
\text { of natural soil }\end{array}$} & \multirow[t]{2}{*}{$\begin{array}{c}\text { Cement } \\
\text { content } \\
(\%)\end{array}$} & \multirow{2}{*}{$\begin{array}{l}\text { Unconfined } \\
\text { compressiv } \\
\text { e strength } \\
\text { of } \\
\text { soil-cement } \\
\quad(\mathrm{kPa})\end{array}$} & \multicolumn{2}{|c|}{$\begin{array}{l}\text { Shear strength } \\
\text { parameters of } \\
\text { soil-cement }\end{array}$} \\
\hline & $\begin{array}{c}\text { Cohesio } \\
\mathrm{n} \\
(\mathrm{kPa})\end{array}$ & $\begin{array}{c}\text { Angle of } \\
\text { internal friction } \\
\text { (degrees) }\end{array}$ & & & $\begin{array}{c}\text { Cohesio } \\
n \\
(\mathrm{kPa})\end{array}$ & $\begin{array}{c}\text { Angle of } \\
\text { internal } \\
\text { friction } \\
\text { (degrees) }\end{array}$ \\
\hline \multirow{3}{*}{29.1} & \multirow{3}{*}{25.2} & \multirow{3}{*}{10} & 7 & 460 & 118 & 22 \\
\hline & & & 10 & 800 & 211 & 25 \\
\hline & & & 15 & 1290 & 283 & 32 \\
\hline
\end{tabular}

\section{Acknowledgements}

This work was financially supported by Shandong Traffic Technology Projects (2006Y009).

\section{References}

[1] Junjie Zheng.Ground improvement techniques, Huazhong Science and Technology University Press. 2009.9,pp. 152-156. (In Chinese).

[2] Test Methods of Soils Highway Engineering. (JTG E40-2007).pp. 67-92. (In Chinese).

[3] Xiaonan Gong.Technology development and prospect of foundation treatment. China's Water Conservancy and Hydropower Press 2004,pp. 85-90. (In Chinese).

[4] Guanghui Shao,Wu Nengsen.Soil Mechanism and Foundation. People's Traffic Press.2007,pp. 285-286. (In Chinese).

[5] Xizhe Chen.Soil Mechanics and Geotechnical Engineering. Tsinghua University Press.2004.4, pp. 455-456. (In Chinese). 